\title{
APPLICABILITY OF THE SWAT HYDROLOGICAL MODEL IN THE MUCURI RIVER BASIN
}

\author{
Rafael A. Almeida ${ }^{1 *}$, Silvio B. Pereira ${ }^{2}$, Daniel B. F. Pinto ${ }^{1}$, David R. Q. Rosa ${ }^{3}$ \\ ${ }^{1 *}$ Corresponding author. Universidade Federal dos Vales do Jequitinhonha e Mucuri (UFVJM)/ Teófilo Otoni - MG, Brasil. \\ E-mail: rafael.almeida@ufvjm.edu.br | ORCID ID: https://orcid.org/0000-0002-3828-7305
}

\section{KEYWORDS}

land use scenarios, hydrological modeling, streamflow.

\begin{abstract}
Land-use changes promote significant variations in streamflow regimes, and hydrological models allow studying their impacts. Based on this approach, this study aimed to assess the applicability of the SWAT model for different land-use scenarios and their respective impacts on the flow regime of the Mucuri River. The average monthly and daily water balance was generated after the calibration and validation of the SWAT model in the basin. Three land-use scenarios were analyzed in relation to the current land use, as follows: replacement of the agricultural area by the eucalyptus crop, replacement of the native forest area by the sugarcane crop, and replacement of pasture by exposed soil. The results showed that the SWAT model is adequate to simulate the land-use change and its impact on the flow regime of the Mucuri River; the replacement of agriculture by eucalyptus in the basin led to a decrease in the average and minimum reference streamflows; and the replacement of the forest cover by sugarcane and pasture by exposed soil provided an increase in the average and minimum reference streamflows.
\end{abstract}

\section{INTRODUCTION}

In general, the intense and disordered replacement of natural landscapes by more intensive land uses has contributed significantly to the deterioration of the quality and quantity of water resources. Knowledge of the effects of land-use change on the qualitative and quantitative dynamics of water resources is necessary to mitigate this important environmental impact. These studies may allow the development of public policies to assist decision-making, aiming at the management of water resources, as well as incentives to soil and water conservation practices.

Land use affects the partition effects of the components of the hydrological cycle on runoff and water infiltration in the soil, in addition to the magnitude of evapotranspiration (Tucci, 2005; Mehnaza, 2017).

The soil and water assessment tool (SWAT) hydrological model is a semi-distributed model created to study the effect of land use management on various components, such as flows, sediments, pesticides, and nutrients. It has an important interface with the geographic information systems, facilitating the entry, manipulation, and editing of databases that feed the system (Andrade et al., Monteiro et al., 2015).

The SWAT model can operate on a daily, monthly, and annual time scale, being efficient to simulate decades and used to predict the behavior of a basin in the long term, but it cannot simulate isolated events, such as intensity and duration of precipitation and propagation of a flood event (Arnold et al., 1998; Neitsch et al., 2005; Winchell et al., 2009).

The input data of this model are the main obstacle for Brazilian conditions, as the data acquisition system is out of date, with flaws and in a less quantity than it should have for more reliable modeling. These factors contribute to the inefficiency in the application of more robust hydrological models in Brazilian basins (Bressiani et al., 2015).

The SWAT model establishes a basic sequence of data for its operation, consisting of steps of sensitivity analysis, calibration of model parameters, validation of parameters, and simulations of the hydrological process of according to different variations as long as the model has a satisfactory performance (Neitsch et al., 2005).

\footnotetext{
${ }^{1}$ Universidade Federal dos Vales do Jequitinhonha e Mucuri (UFVJM) /Teófilo Otoni - MG, Brasil.

${ }^{2}$ In memoriam.

${ }^{3}$ Instituto Federal de Educação, Ciência e Tecnologia do Sudeste de Minas Gerais (IFSudesteMG)/ Manhuaçu - MG, Brasil.
} 
The advantages of hydrological modeling are several, from issues related to the planning and management of water resources to public safety in extreme events, such as floods or drought. In this context, studies related to hydrological modeling have become suitable for the different Brazilian edaphoclimatic conditions, but a consistent database is necessary (Abbaspour et al., 2015; Meaurio et al., 2015; Awan \& Ismaeel, 2014; Zhang et al., 2019).

The simulation of different land uses has been intensively studied aiming at analyzing the impact of their variation in the streamflow regime, as well as the impact on the entire system that governs the hydrological cycle (Blainski et al., 2011; Durães et al., 2011; Beskow et al., 2011, Zhu et al., 2016). Pereira et al. (2014) used the SWAT model on a daily scale in a basin of the state of Espírito Santo and found that the model satisfactorily met the modeling of the annual daily minimum streamflows and the minimum reference streamflows $\mathrm{Q}_{90}$ and $\mathrm{Q}_{95}$, but not being suitable for annual daily maximum streamflows.

The SWAT model has been efficient in assessing the impacts of soil cover change and climate variation in different basins throughout the planet and providing information to support analysis for decision making in water resources management (Durães et al., 2011; Pinto, 2011).

Based on this approach, this study aimed to assess the applicability of the SWAT model for various soil use conditions and their respective impacts on the flow regime of the Mucuri River basin.

\section{MATERIAL AND METHODS}

\section{Characterization of the study area}

The Mucuri River basin (Figure 1) is inserted in the East Atlantic basin, extending to 17 municipalities, of which 13 are in the state of Minas Gerais (95\% of the basin area) and the other four in the states of Espírito Santo and Bahia. It comprises an area of about 15,400 $\mathrm{km}^{2}$, with a population of approximately 450,000 inhabitants, bordering the Jequitinhonha, Peruíbe, São Mateus, and Doce River basins. The Mucuri River basin has extensive mining activity, mainly in the city of Teófilo Otoni, in addition to agriculture, livestock, and reforestation activities (IGAM, 2015).

The climate in the Mucuri valley is characterized as a semi-humid warm tropical climate of the Aw type, according to the Köppen classification (Kottek et al., 2006). According to the classification proposed by the Ecological Zoning of the State of Minas Gerais (ZEE$\mathrm{MG})$, the climate can be called dry sub-humid (C1), with a range of humidity index ranging from -33.3 to 0 , annual precipitation ranging from 850 to $1,100 \mathrm{~mm}$, and average annual temperatures between 21 and $28{ }^{\circ} \mathrm{C}$ (Scolforo et al., 2008).

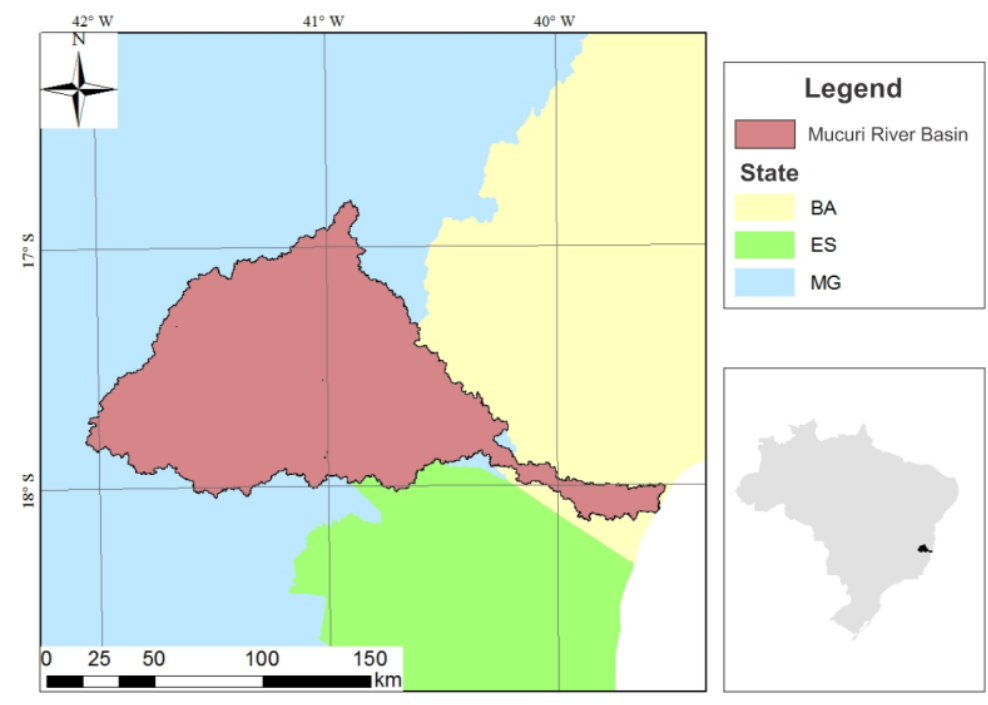

FIGURE 1. Spatial location of the Mucuri River basin.

\section{SWAT}

The computer simulation was performed with the SWAT version 2012 (Arnold et al., 2012), through the interface with ArcGIS 10.x, named ARCSWAT, which was systematically described by Almeida et al., (2018).

Database used in the simulation
The relief data were obtained by the hydrographically conditioned digital elevation model (HCDEM) prepared based on altimetric data derived from the shuttle radar topographic mission (SRTM), according to the methodology proposed by Elesbon et al. (2011). Its spatial distribution is shown in Figure 2, with elevations ranging from 1 (river mouth region) to $1,238 \mathrm{~m}$ (headwater region). 


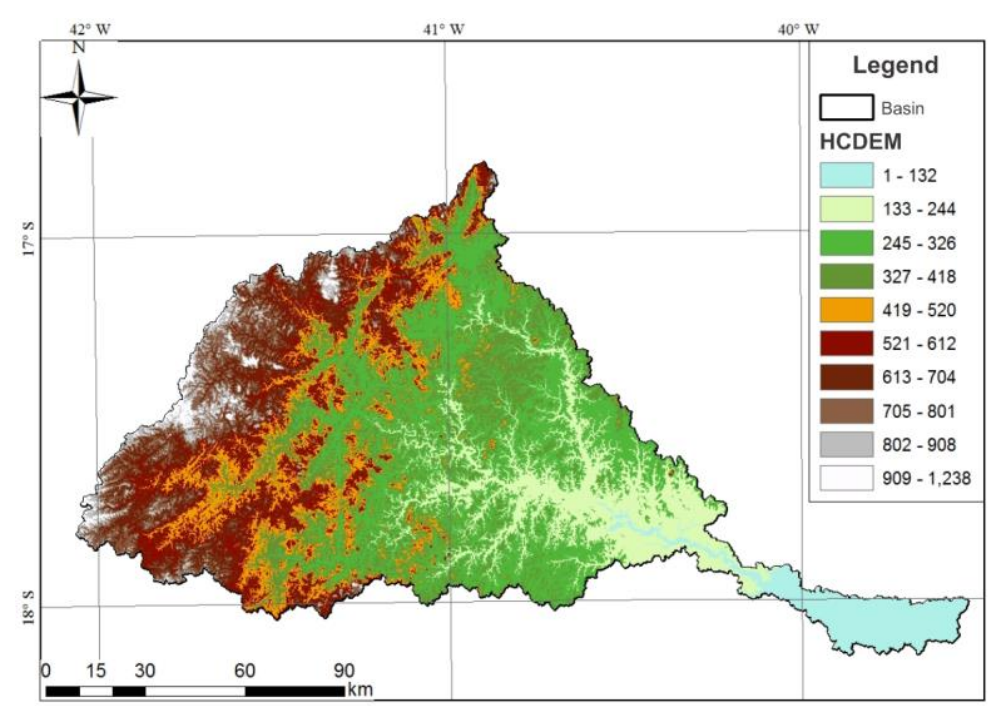

FIGURE 2. Hydrographically conditioned digital elevation model (HCDEM) of the Mucuri River basin.

The slope classes proposed by Embrapa (1979) were used to delimitate the hydrological response units (HRU), obtained based on HCDEM.

The soil map was adapted from the study carried out by the Soil Department of the Federal University of
Viçosa, which mapped the entire Mucuri River basin (Figure 4.3), showing seven main soil types, namely: Cambisols (0.5\%), Gleysols (0.5\%), Latosols (50.4\%), Argisols (45.6\%), Mangrove soils (0.1\%), Spodosols $(0.3 \%)$, and rocky outcrops $(2.6 \%)$.

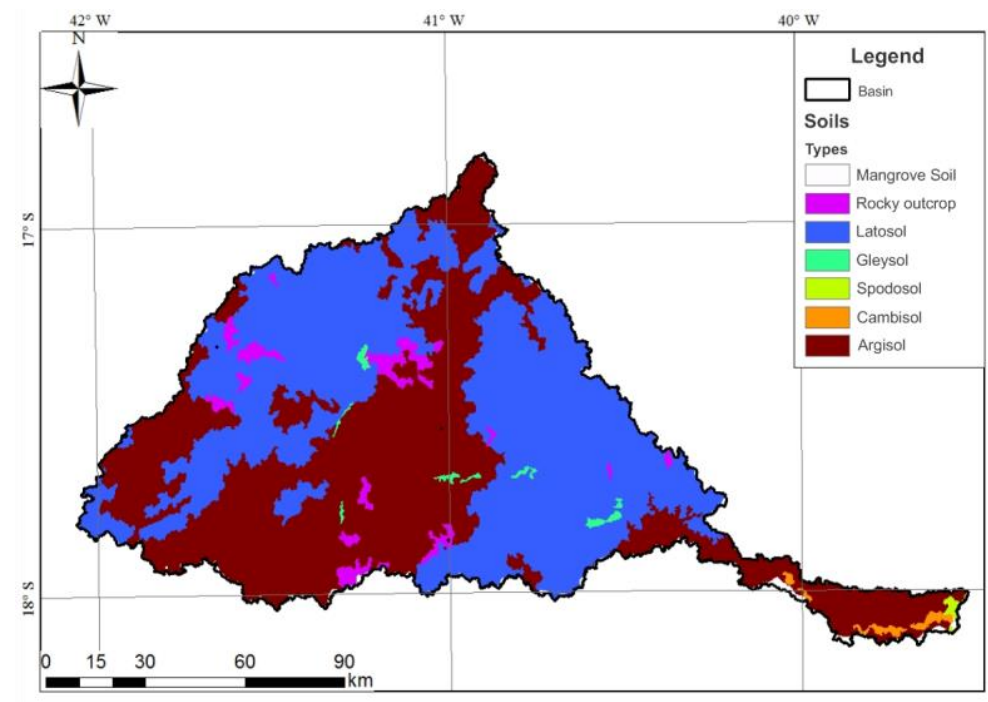

FIGURE 3. Main soil types in the Mucuri River basin.

The physio-hydric attributes required for the model were obtained from previous studies carried out in other basins, according to Pinto (2011), Lelis (2011), and Oliveira (2014).
The land use map of the Mucuri River basin was obtained through a supervised classification by the maximum likelihood method using a mosaic of LANDSAT 8 images, with a 30-m spatial resolution (Figure 4). 


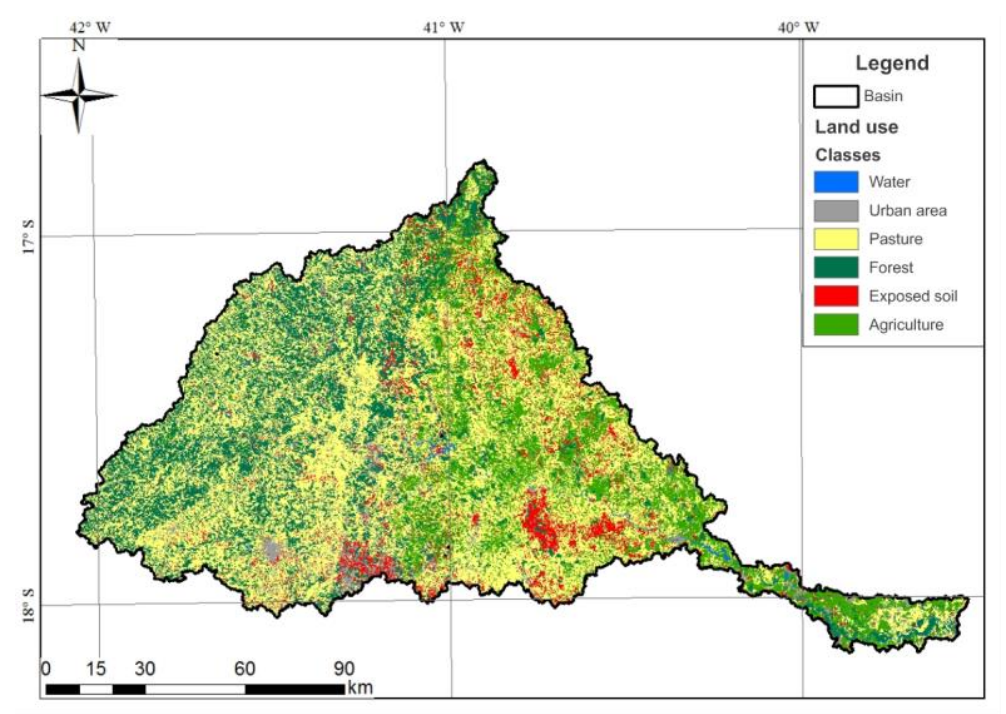

FIGURE 4. Map of land use and occupation of the Mucuri River basin.

The region has a predominance of pasture (47.1\%), followed by forest cultivation (23.2\%), agriculture (16.1), exposed soil (6.7\%), urban area $(6.4 \%)$, and water $(0.5 \%)$.

The climate data entry for the model was obtained by the HIDROWEB/ANA database and the INMET network of automatic stations. Eight pluviometric, six fluviometric, and two meteorological stations were used considering the base period from
$01 / 01 / 2007$ to $12 / 31 / 2014$.

The daily data of precipitation ( $\mathrm{mm})$, maximum and minimum temperature $\left({ }^{\circ} \mathrm{C}\right)$, solar radiation $\left(\mathrm{MJ} \mathrm{m}^{-2}\right.$ $\left.\mathrm{s}^{-2}\right)$, wind speed $\left(\mathrm{m} \mathrm{s}^{-1}\right)$, and relative humidity $(\%)$ were obtained from the meteorological stations, while the precipitation $(\mathrm{mm})$ and streamflow $\left(\mathrm{m}^{3} \mathrm{~s}^{-1}\right)$ data were obtained from the pluviometric and fluviometric stations, respectively. Other important information from the stations is shown in Table 1.

TABLE 1. Information regarding the hydrological and meteorological stations.

\begin{tabular}{ccccc}
\hline Code & Type & Name & Municipality & Responsible \\
\hline 55630000 & $\mathrm{~F}^{1}$ & CARLOS CHAGAS & CARLOS CHAGAS & ANA $^{4}$ \\
55560000 & $\mathrm{~F}$ & FAZENDA DIACUI & TEÓFILO OTONI & ANA \\
55610000 & $\mathrm{~F}$ & FRANCISCO SÁ & CARLOS CHAGAS & ANA \\
55660000 & $\mathrm{~F}$ & SÃO PEDRO DO PAMPÃ & UMBURATIBA & ANA \\
55699998 & $\mathrm{~F}$ & NANUQUE MONTANTE & NANUQUE & ANA \\
55520001 & $\mathrm{~F}$ & MUCURI & TEÓFILO OTONI & ANA \\
OMM 86763 & $\mathrm{M}^{2}$ & SERRA DOS AIMORÉS & NANUQUE & INMET $^{5}$ \\
OMM 86762 & $\mathrm{M}$ & TEÓFILO OTONI & TEÓFILO OTONI & INMET $^{2}$ \\
1740000 & $\mathrm{P}^{3}$ & CARLOS CHAGAS & CARLOS CHAGAS & ANA \\
1740001 & $\mathrm{P}$ & NANUQUE - MONTANTE & NANUQUE & ANA \\
1740026 & $\mathrm{P}$ & SÃO PEDRO DO PAMPÃ & UMBURATIBA & ANA \\
1740033 & $\mathrm{P}$ & ÁGUAS FORMOSAS & ÁGUAS FORMOSAS & ANA \\
1741001 & $\mathrm{P}$ & MUCURI & TEÓFILO OTONI & ANA \\
1741007 & $\mathrm{P}$ & PEDRO VERSIANI (EFBM) & TEÓFILO OTONI & ANA \\
1741009 & $\mathrm{P}$ & FRANCISCO SÁ (EFBM) & CARLOS CHAGAS & ANA \\
1841008 & $\mathrm{P}$ & ATALÉIA & ATALÉIA & ANA \\
\hline
\end{tabular}

${ }^{1}$ F: fluviometric station; ${ }^{2}$ M: meteorological station; ${ }^{3}$ P: pluviometric station; ${ }^{4}$ ANA: Brazilian National Water Agency; ${ }^{5}$ INMET: Brazilian National Institute of Meteorology.

\section{Sensitivity analysis, calibration, and validation}

The SUFI2 module from the software SWATCUP version 5.1.6 was used in the stages of sensitivity analysis, calibration, and validation of the SWAT model for the Mucuri River basin (Abbaspour, 2007).

Nineteen main parameters (Table 2) was defined for the streamflow calibration in the basin according to the occurrence of the calibratable parameters for the streamflow variable (Blainski et al., 2011; Durães et al., 2011; Muleta \& Nicklow, 2005; Neto et al., 2014; Andrade et al., 2013; Pinto, 2011).

The calibration stage began after the parameters were defined, starting from 250 iterations per simulation until it reached the objective function (Abbaspour, 2007; 
Dar, 2017). The objective function was defined as the Nash-Sutcliffe coefficient (Nash \& Sutcliffe, 1970), opting for the value 0.6 as being appropriate, according to Moriasi et al. (2007).
The ranking of parameters of the sensitivity analysis, the definition by the iteration method, and the calibration intervals are important for the calibration, as shown in Table 2.

TABLE 2. Ranking of the sensitivity analysis, methods, initial adjustment intervals, and calibrated value for the parameter.

\begin{tabular}{|c|c|c|c|c|c|}
\hline Parameter & Ranking & Method & Initial value & Maximum initial value & Calibrated value \\
\hline CH_N2 & 1 & Absolute & 0.01 & 0.059 & 0.116929 \\
\hline GWQMN & 2 & Absolute & -500 & 1000 & 1365.775 \\
\hline CH_K2 & 3 & Absolute & 0 & 25 & 8.948516 \\
\hline EPCO & 4 & Absolute & 0 & 1 & -0.16168 \\
\hline SOL_K & 5 & Relative & -0.9 & 0.9 & -0.40892 \\
\hline SOL_AWC & 6 & Relative & -0.25 & 0.25 & -0.21873 \\
\hline SLSUBBSN & 7 & Relative & -0.25 & 0.25 & 0.059871 \\
\hline SOL_Z & 8 & Relative & -0.25 & 0.25 & 0.164637 \\
\hline CANMX & 9 & Absolute & 0 & 10 & 14.94177 \\
\hline ESCO & 10 & Absolute & 0 & 1 & 0.786809 \\
\hline GW_DELAY & 11 & Absolute & 10 & 120 & 82.0119 \\
\hline GW_REVAP & 12 & Absolute & 0.02 & 0.2 & 0.33627 \\
\hline BIOMIX & 13 & Absolute & 0 & 1 & 0.687435 \\
\hline SURLAG & 14 & Absolute & 0.5 & 10 & 1.664087 \\
\hline ALPHA_BF & 15 & Relative & 0 & 0.048 & 0.004285 \\
\hline REVAPMN & 16 & Absolute & -50 & 100 & 40.74179 \\
\hline SLSOIL & 17 & Relative & -0.5 & 0.5 & -0.59382 \\
\hline $\mathrm{CN} 2$ & 18 & Relative & -0.3 & 0.3 & -0.65569 \\
\hline SOL_ALB & 19 & Relative & -0.25 & 0.25 & -0.15716 \\
\hline
\end{tabular}

The definition of the method and minimum and maximum initial value took into account other studies (Pinto, 2011; Lelis, 2011; Oliveira, 2014). The SWATCUP after each iteration suggests new interval values, always aiming at the optimization of the objective function. The calibrated value of the parameter may be out of the minimum and maximum initial interval due to this characteristic.

In this study, we decided to calibrate in a fluviometric station and perform the validation in the other stations of the basin. This technique is related to the modeling premise because the model must be able to respond to the entire hydrological process that occurs in the basin for the calibration conditions.

Figure 5 shows the spatial distribution of the fluviometric stations and the drainage area of the calibration station. The Nash-Sutcliffe efficiency index at Carlos Chagas station (55630000), which has a drainage area of $9,160 \mathrm{~km}^{2}$, was 0.63 , classified as good according to Moriasi et al. (2007), Van Liew et al. (2003), and Fernandez et al. (2005). More details on the sensitivity analysis, calibration, and validation process are described by Almeida et al., (2018). 


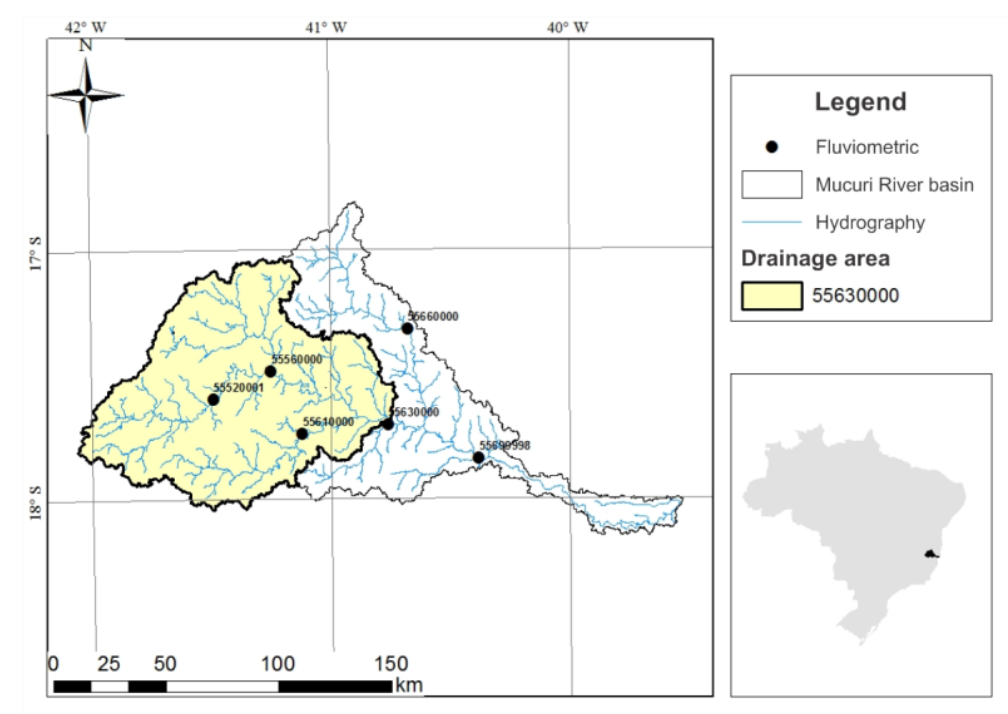

FIGURE 5. Distribution of the fluviometric stations and drainage area of the station used for calibration.

\section{Applicability of the model in the basin}

The applicability of the SWAT model in the Mucuri River basin was assessed by generating the average monthly and daily water balance in the analyzed period. The elaboration of the water balance considered the precipitation, actual and potential evapotranspiration, surface runoff, base runoff, and water production in the basin. Moreover, alternative land-use scenarios and their impacts on the streamflow regime of the basin were proposed aiming at the applicability of the model. The proposed scenarios sought to simulate the possible extremes of land-use change trends, as shown in Table 3.

TABLE 3. Proposed land-use change scenarios.

Land-use change

Scenario 1

Scenario 2

Scenario 3

Replacement of the general agriculture area by the eucalyptus crop

Replacement of the forest area by the sugarcane crop

Replacement of the pasture area by the exposed soil area

These scenarios are justified by regional trends, as pulp and paper processing industries (Scenario 1) and a sugar-energy plant (Scenario 2) are present in the basin. Scenario 3 is justified because pasture is the largest area of land use in the region, not being recognized as a crop, but rather as extractivism, i.e., little managed areas led to degradation over time.

The daily streamflow, average streamflow, average monthly streamflows, permanence curve, and minimum reference streamflows $\left(\mathrm{Q}_{7,10}\right.$ and $\left.\mathrm{Q}_{90}\right)$ were determined for the period of study to analyze the impacts proposed by the land-use change scenarios in the water resources.

\section{RESULTS AND DISCUSSION}

Figure 6 shows the simulated and observed hydrographs and precipitation obtained from the calibration of the SWAT model for the Carlos Chagas station (55630000). The results were considered good according to the obtained statistical indices, indicating that the model was efficient to simulate the streamflow behavior in the control section established by the station, in both flood and drought periods (Almeida et al., 2018). However, problems of underestimating the simulated values were observed, in general, at flow peaks. Several studies have reported similar results (Aragão et al., 2013; Brighenti et al., 2016). 


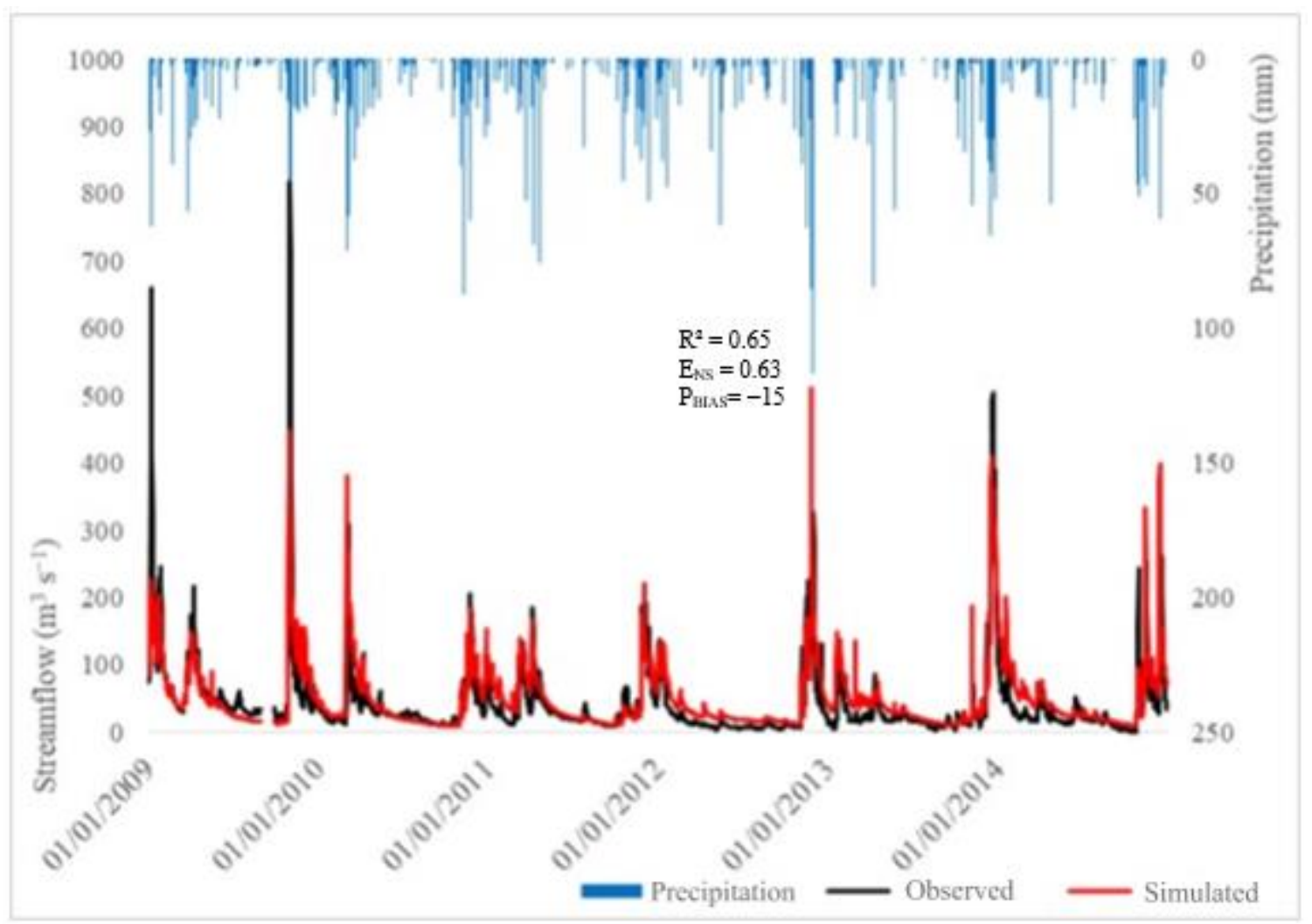

FIGURE 6. Precipitation, observed and simulated hydrograph for the station 55630000 (Carlos Chagas) used for calibrating the SWAT model upstream of the section.

Figure 7 shows the average monthly water balance obtained for the region upstream of the station calibrated for the period from 2009 to 2014.

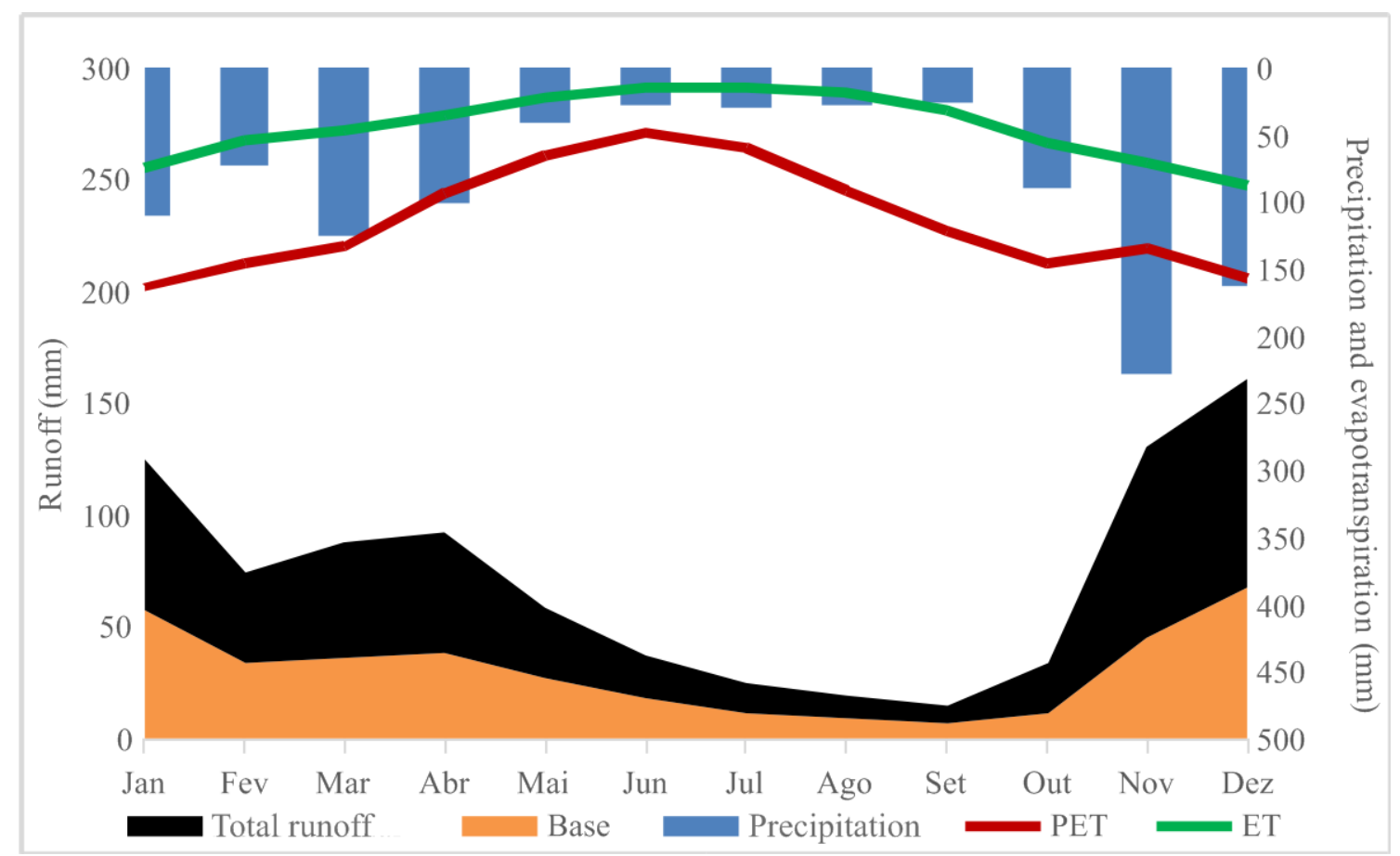

FIGURE 7. Average monthly water balance simulated for Carlos Chagas station (55630000). Base indicates the base runoff; PET indicates the potential evapotranspiration, and ET indicates the actual evapotranspiration. 
Figure 7 shows that the region has two distinct periods of precipitation, i.e., a wet (October to April) and a dry period (April to October). This behavior is expected for the Southeast and Northeast regions of Brazil (Almeida et al., 2015).

The actual evapotranspiration (ET) was significantly lower than the potential evapotranspiration (PET) because the region is inserted in a transition zone from the semi-humid to the semiarid climate. However, the water balance in September operated in a water deficit (actual evapotranspiration higher than precipitation), which leads to a trend to decrease groundwater resources, as the amount of precipitation was low in the period. The parameters related to groundwater can also explain this behavior since they were the most sensitive in the model calibration for the basin (CH_N2, GWQMN, CH_K2, EPCO, SOL_K, and SOL_AWC).

Moreover, Figure 7 shows that the total runoff refers to the sum of the components of the surface and underground flow (surface + base). The direct impact of the dry period on the streamflow is observed, with the direct (surface) flow ceasing and the water production being maintained basically by the underground flow (base). Thus, the recharge of underground water sources occurs from October to January.

The highest incidence of direct runoff is observed during November and December, as this period is the middle of the rainy season. This behavior occurs because the soil is already with high moisture, thus favoring the formation of direct surface runoff.

Figure 8 represents the daily water balance for the analyzed period. Flow peaks occur predominantly in the rainy season, especially from December to January. These peaks are characterized by high precipitation levels associated with periods of high soil moisture in the period before the rain event, favoring the formation of direct runoff.

An unusual period of drought (dry spell) was observed in January and February 2010, with precipitation values of 21 and $55 \mathrm{~mm}$, respectively. However, the average precipitation was $110 \mathrm{~mm}$ in January and $72 \mathrm{~mm}$ in February (Figure 7). This type of event directly impacts the recharge of underground water sources, rapidly decreasing the streamflow in the period where recharge should occur.

Figure 9 shows the hydrographs generated by land-use changes in the analyzed period, according to the proposed scenarios: Scenario 1 - replacement of the agricultural area by the eucalyptus crop; Scenario 2 replacement of the forest cover by the sugarcane cultivation; and Scenario 3 - replacement of pasture by exposed soil. Scenarios 1 and 2 showed small changes relative to the current scenario most of the time, but Scenario 3 presented the most expressive differences.

The similar behavior of Scenarios 1 and 2 is mainly associated with the range of values of the curve number $(\mathrm{CN})$ be close in the proposals for land-use changes. Another fact that explains this similarity is that the $\mathrm{CN} 2$ parameter was not very sensitive to calibration in the basin, according to the sensitivity analysis.

Scenario 3 showed the highest flow peaks and higher streamflow in the recession phases of the direct runoff. This behavior is expected because the change from pasture cover to exposed soil leads to an increase in the runoff component, which is associated with a rapid flow response compared to the precipitation.

Pereira (2013) obtained similar results when simulating the variation of land use in a hydrographic basin, but with no major changes in the hydrographs.

Table 4 shows the values of the average streamflow and the variation in the average streamflow relative to the current land use for the analyzed period. Scenario 1 showed average streamflow of $83,158 \mathrm{~m}^{3} \mathrm{~s}^{-1}$, representing a $1.79 \%$ reduction relative to the current scenario, and an increase of around 5\% for the simulation in Scenario 2. Moreover, Scenario 3 showed a $22.60 \%$ increase compared to the current land use scenario.

TABLE 4. Average streamflow and percentage of increment simulated for different land-use scenarios.

\begin{tabular}{ccc}
\hline Land use & Average streamflow $\left(\mathrm{m}^{3} \mathrm{~s}^{-1}\right)$ & $\begin{array}{c}\text { Variation } \\
\text { (\% relative to the current use) }\end{array}$ \\
\hline Current & 84.675 & -1.79 \\
Scenario 1 & 83.158 & 5.14 \\
Scenario 2 & 89.030 & 22.60 \\
Scenario 3 & 103.809 & \\
\hline
\end{tabular}

The decrease in the average streamflow for Scenario 1 occurs because the replacement of the agriculture area by eucalyptus tends to increase the evapotranspiration component, consequently decreasing the streamflow. This fact leads to an increase in water consumption due to evapotranspiration, as the main contributions to the streamflow in the basin are from groundwater. 


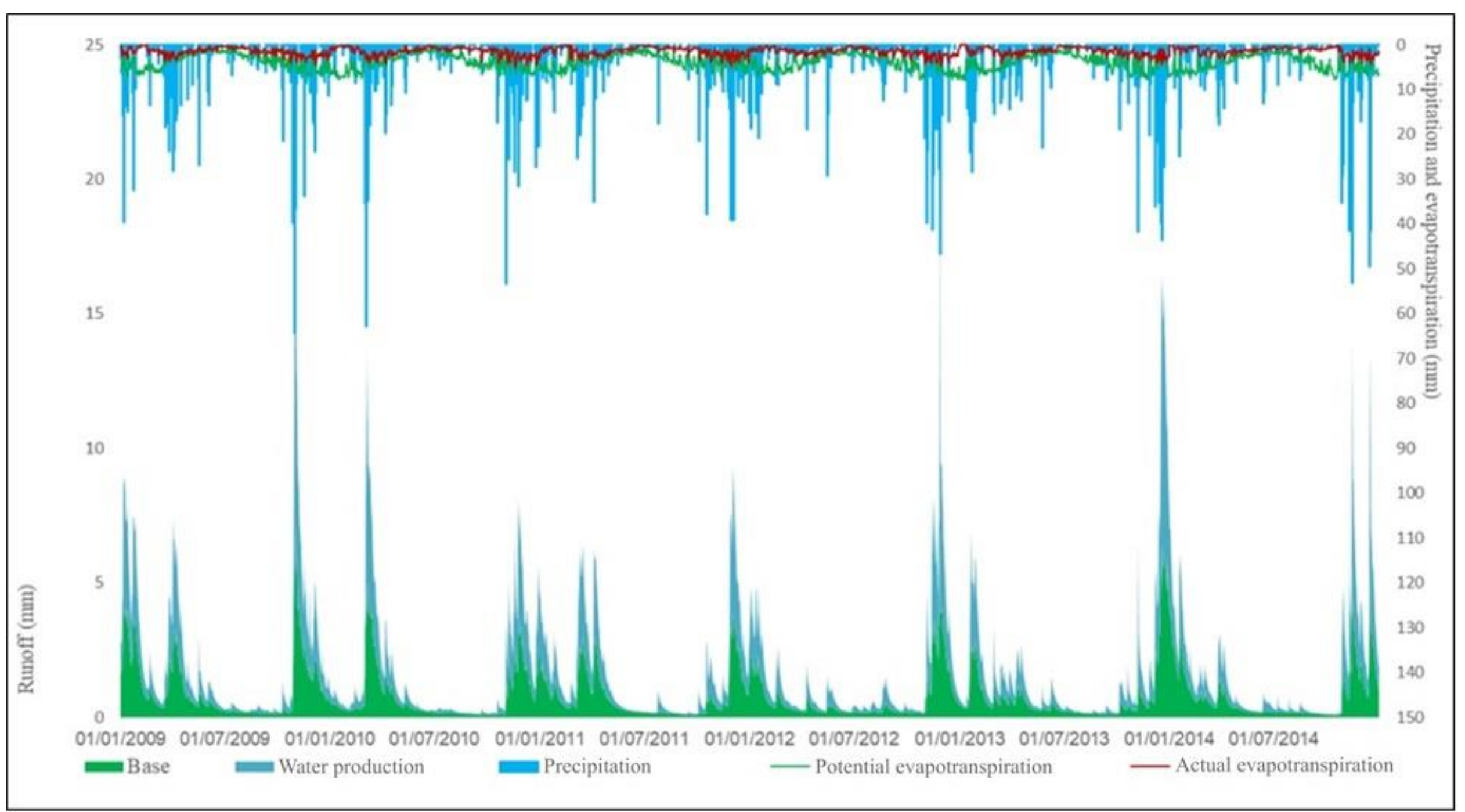

FIGURE 8. Daily water balance. 


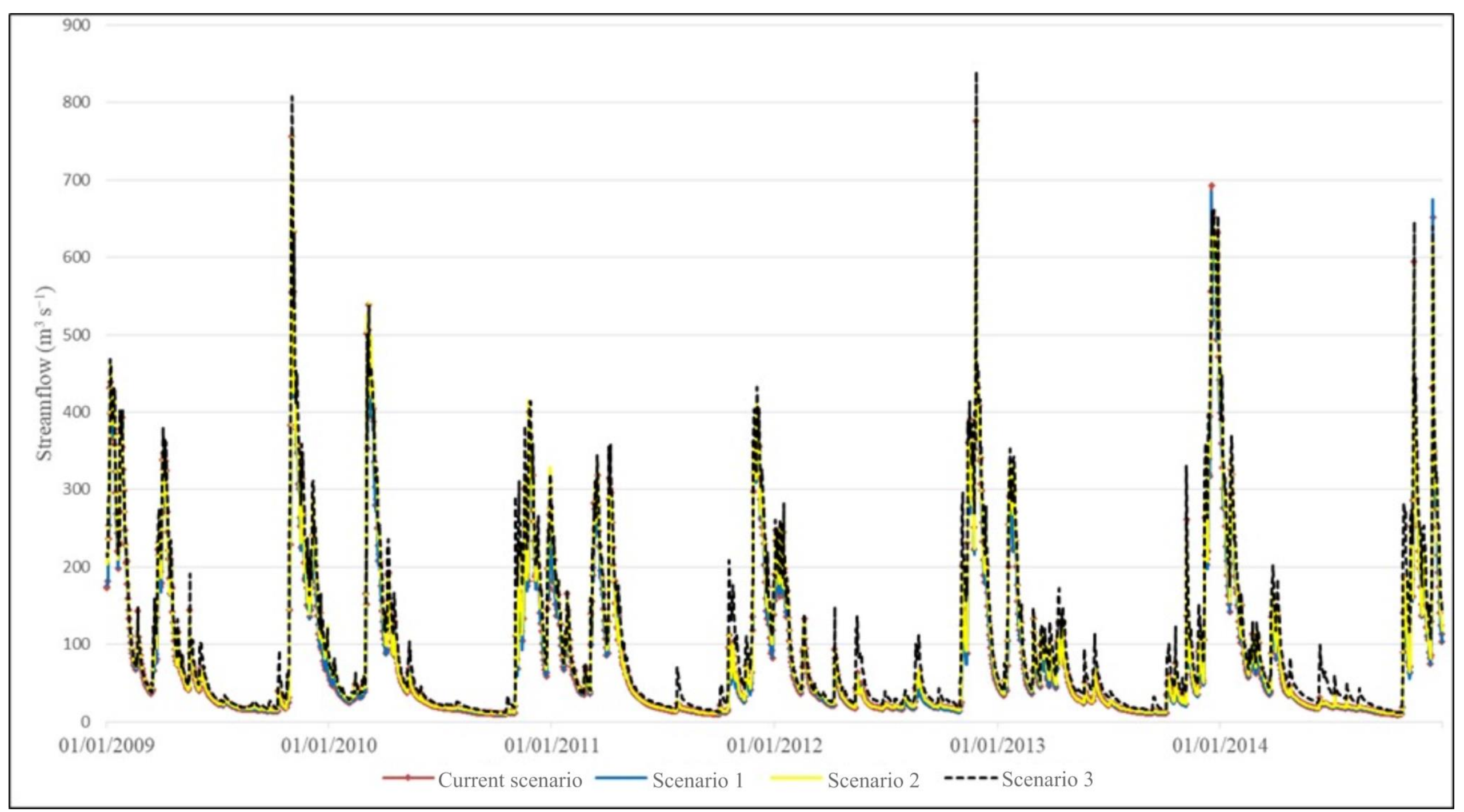

FIGURE 9. Hydrographs generated by simulating land-use change scenarios for the Mucuri River basin. 
The increase in the average streamflow in Scenario 2 can also be explained by the same fact, as the plant mass decreases, replacing the forest area with sugarcane, the evapotranspiration component also decreases, leading to an increase in the average streamflow. These results corroborate the statement presented by Bosch \& Hewlett (1982), who reported an increase in the average streamflow with the removal of forest cover.

The increase in the average streamflow in Scenario 3 is explained by an increase in the direct runoff component and a decrease in evapotranspiration due to an increase in the curve number $(\mathrm{CN})$ and reduction in the vegetation cover. Blainski et al. (2011) also observed an increase in the average flow when replacing the vegetated area by exposed soil. This fact corroborated to support the obtained results.

Perazzoli et al. (2013) proposed three different land-use change scenarios for the Concórdia River basin in the state of Santa Catarina, in the South of Brazil, with predominant land use for forest cover $(\sim 67 \%)$, followed by pasture area $(\sim 20 \%)$, and agriculture $(\sim 17 \%)$. They found that replacing the entire basin area by agriculture, forest, and pasture did not change, decreased, and increased the average flow, respectively.

Figure 10 shows the average monthly streamflow for the different land-use scenarios. Scenario 1 was presented a behavior very similar to that of the current scenario. A slight increase in the average monthly streamflow was also observed for Scenario 2 in relation to the current scenario and a higher increase in Scenario 3 in all months.

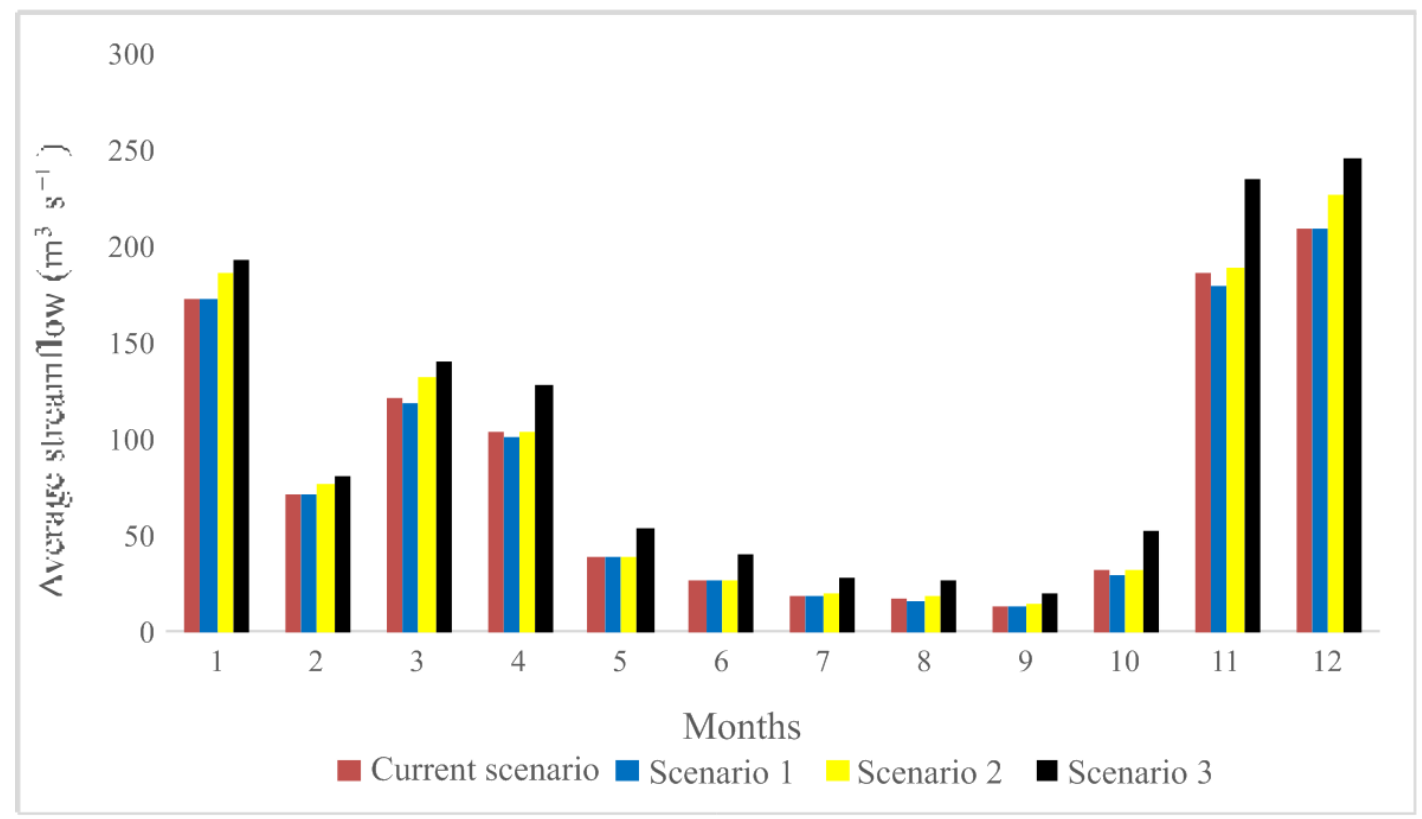

FIGURE 10. Average monthly streamflow simulated for different land uses.

Figure 11 shows the permanence curve of the simulated streamflows for the different land-use scenarios. The different scenarios showed a certain similarity, with the streamflows for Scenario 3 being higher than the current land use and Scenarios 1 and 2. In addition, the minimum streamflows in some regions of Brazil are obtained as a function of the permanence curve. 


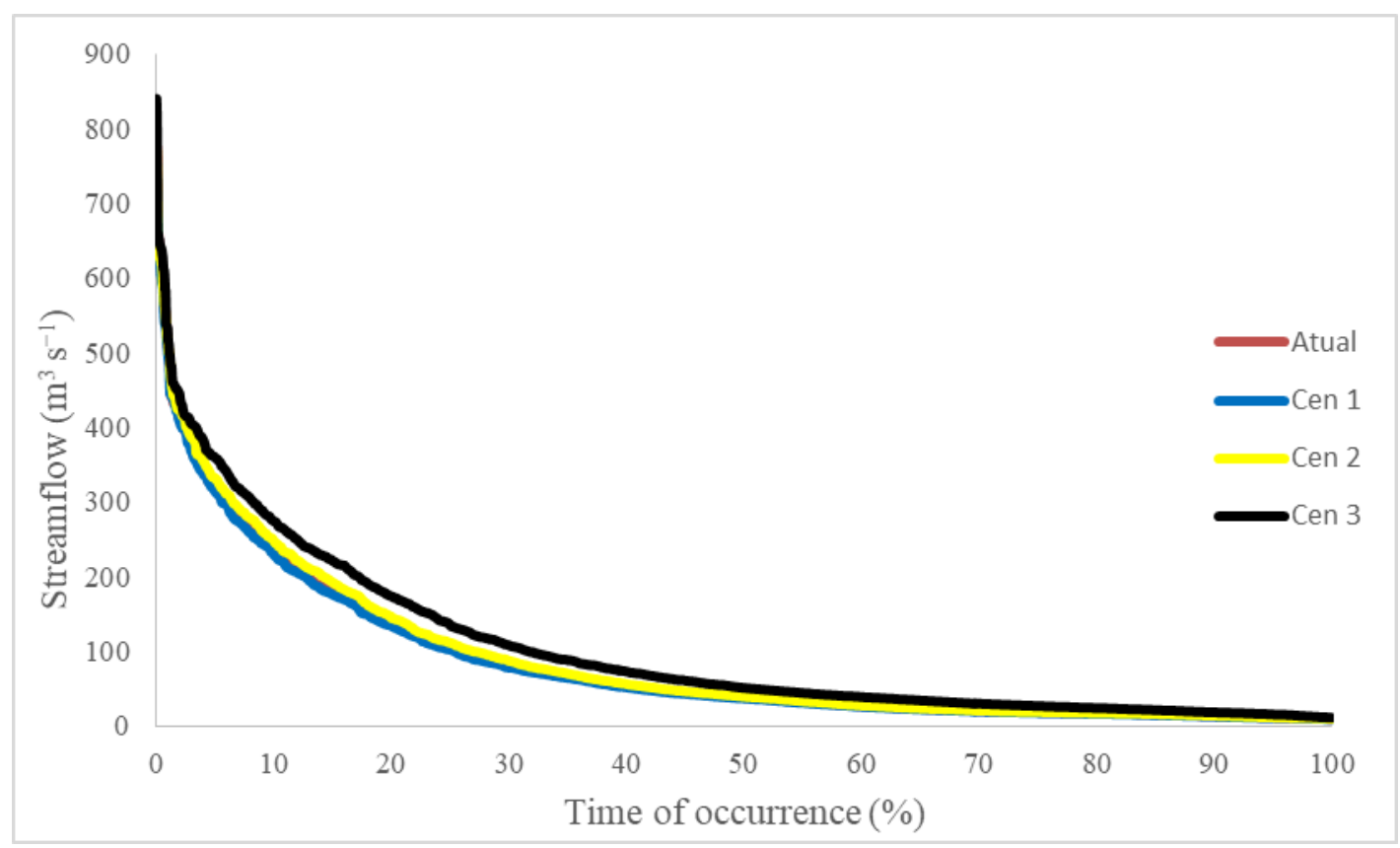

FIGURE 11. Permanence curve of streamflows simulated for different land uses.

Table 5 shows the values of the minimum reference streamflows $\left(\mathrm{Q}_{7,10}\right.$ and $\left.\mathrm{Q}_{90}\right)$, simulated for the different scenarios proposed in this study. Land-use change presented a higher impact on the minimum reference streamflows, especially in Scenario 3, with an increase of $12.02 \%$ in $\mathrm{Q}_{7,10}$ and $39.63 \%$ in $\mathrm{Q}_{90}$. Scenario 1 showed a decrease in $\mathrm{Q}_{7,10}$ and $\mathrm{Q}_{90}$ of 0.73 and 3.20\%, while Scenario 2 showed an increase in the streamflows of 3.07 and $4.88 \%$, respectively.

TABLE 5. Values of minimum reference streamflows and their variation for different land-use scenarios.

\begin{tabular}{lcccc}
\hline Land use & $\mathrm{Q}_{7,10}\left(\mathrm{~m}^{3} \mathrm{~s}^{-1}\right)$ & Variation $(\%)$ & $\mathrm{Q}_{90}\left(\mathrm{~m}^{3} \mathrm{~s}^{-1}\right)$ & Variation $(\%)$ \\
\hline Current scenario & 1.239 & - & 11.280 & - \\
Scenario 1 & 1.230 & -0.73 & 10.910 & -3.20 \\
Scenario 2 & 1.277 & 3.07 & 11.830 & 4.88 \\
Scenario 3 & 1.489 & 12.02 & 15.750 & 39.63 \\
\hline
\end{tabular}

Despite the increases in the average and minimum reference streamflows verified for Scenario 3, the replacement of pasture by exposed soil may not be convenient from the environmental point of view for the basin, as other factors, such as sediment production, nutrient transport, water quality, aquatic microorganisms, influence on the microclimate, and influence on the local fauna and flora, should be analyzed. Moreover, the studied period covers only six years, and longer-term analyses may present different findings from those observed.

\section{CONCLUSIONS}

The SWAT model was efficient to simulate the impact of the land-use change for the proposed scenarios on the flow regime of the Mucuri River basin.

The replacement of agriculture by eucalyptus in the basin led to a decrease in the average and minimum reference streamflow.

The replacement of forest cover by sugarcane and pasture by exposed soil provided an increase in the average and minimum reference streamflow.

It is important to evaluate other environmental aspects to infer the effective quality of natural resources in the Mucuri River basin through land-use change scenarios.

\section{REFERENCES}

Abbaspour KC (2007) SWAT-CUP, SWAT

Calibration and Uncertainty Programs. A user manual. Swiss Federal Institute for Aquatic Science and Technology, Zurich, 84 p. Available:

https://swat.tamu.edu/media/114860/usermanual_swatc up.pdf. Acessed: Sep 08, 2018.

Abbaspour KC, Rouholahnejad E, Vaghefi S, Srinivasan R, Yang H, Kløve B (2015) A continentalscale hydrology and water quality model for Europe: Calibration and uncertainty of a high-resolution largescale SWAT model. Journal of Hydrology 524(1):733752. DOI:

https://doi.org/10.1016/j.jhydrol.2015.03.027

Almeida RA, Pereira SB, Coelho CD, Souza DAN (2015) Precipitação pluvial média mensal e anual nas regiões político-administrativas do Brasil. Engenharia na Agricultura 23(1):169-175. 
Almeida RA, Pereira SB, Pinto DBF (2018) Calibration and validation of the SWAT hydrological model for the Mucuri river basin. Engenharia Agrícola 38(1):55-63. DOI: http://dx.doi.org/10.1590/18094430-eng.agric.v38n1p55-63/2018

Andrade MA, Mello CR, Beskow S (2013) Simulação hidrológica em uma bacia hidrográfica representativa dos Latossolos na região Alto Rio Grande, MG. Revista brasileira de engenharia agrícola e ambiental 17(1):69-76. DOI: http://dx.doi.org/10.1590/S141543662013000100010

Aragão R, Cruz MAS, Amorim JRA, Mendonça LC, Figueiredo EE, Srinivasan VS (2013) Análise de sensibilidade dos parâmetros do modelo SWAT e simulação dos processos hidrossedimentológicos em uma bacia no agreste nordestino. Revista Brasileira de Ciência do Solo 37(4):1091-1102. DOI:

http://dx.doi.org/10.1590/S0100-06832013000400026

Arnold JG, Moriasi DN, Gassman PW, Abbaspour KC, White MJ, Srinivasan R, Santhi C, Harmel RD, Van Griensven A, Van Liew MW, Kannan N, JHA MK (2012) SWAT: model use, calibration, and validation. Transactions of the ASABE 55(4):1491-1508.

Arnold JG, Srinivasan R, Muttiah RS, Williams JR (1998) Large area hydrologic modeling and assessment part I: model development. Journal of the American Water Resources Association 34(1):73-89. DOI: https://doi.org/10.1111/j.1752-1688.1998.tb05961.x

Awan UK, Ismaeel A (2014) A new technique to map groundwater recharge in irrigated areas using a SWAT model under changing climate. Journal of Hydrology 519(1):1368-1382. DOI: https://doi.org/10.1016/j.jhydrol.2014.08.049

Beskow S, Mello CR, Norton LD, Silva AM (2011)

Performance of a distributed semi-conceptual hydrological model under tropical watershed conditions. Catena 86(3):160-171. DOI: https://doi.org/10.1016/j.catena.2011.03.010

Blainski E, Silviera FA, Conceição G, Garbossa LHP, Vianna LF (2011) Simulação de cenários de uso do solo na bacia hidrográfica do rio Araranguá utilizando a técnica da modelagem hidrológica. Revista Agropecuária Catarinense 24(1):65-70.

Bosch J, Hewlett J (1982) A review of catchment experiments to determine the effect of vegetation changes on water yield and evapotranspiration. Journal of Hydrology 55(1):3-23.

Bressiani DA, Gassman PW, Fernandes JG, Garbossa LHP, Srinivasan R, Bonumá NB, Mendiondo EM (2015) Review of Soil and Water Assessment Tool (SWAT) applications in Brazil: Challenges and prospects. International Journal of Agricultural and Biological Engineering 8(3):9-35.

Brighenti TM, Bonumá ND, Chaffe LB (2016) Hierarchical Calibration of SWAT model for a watershed in southern Brazil. Revista Brasileira de Recursos Hídricos 21(1):54-64. DOI: http://dx.doi.org/10.21168/rbrh.v21n1.p53-64
Dar LA (2017) Rainfall-runoff modeling using multiple linear regression technique. International Journal for Research in Applied Sciences, Engineering and Technology 5(7):214-218.

Durães MF, Mello CR, Naghettini M (2011) Applicability of the SWAT model for hydrologic simulation in Paraopeba river basin, MG. Cerne 17(4):481-488. DOI: http://dx.doi.org/10.1590/S010477602011000400006

Elesbon AAA, Guedes HAS, Silva DD, Oliveira IC (2011) Uso de dados SRTM e plataforma SIG na caracterização morfométrica da bacia hidrográfica do Braço Norte do Rio São Mateus - Brasil. Revista Escola de Minas 64(3):281-288. DOI: http://dx.doi.org/10.1590/S0370-44672011000300005

Embrapa - Empresa Brasileira de Pesquisa

Agropecuária (1979) Serviço nacional de levantamento e conservação de solos, Súmula da 10 Reunião Técnica de Levantamento de Solos. Embrapa, 83p.

Fernandez GP, Chescheir GM, Skaggs RW, Amatya DM (2005) Development and testing of watershedscale models for poorly drained soils. Transactions of the ASAE 48(2):639-652.

IGAM - Instituto Mineiro de Gestão das Águas (2015) Plano estadual de recursos hídricos - IGAM, 139p.

Kottek M, Grieser J, Beck C, Rudolf B, Rubel F (2006) World Map of the Köppen-Geiger climate classification updated. Meteorologische Zeitschrift, 15 (3): 259-263. DOI: https://doi.org/10.1127/09412948/2006/0130

Lelis TA (2011) Modelagem do escoamento superficial e da perda de solo na bacia do ribeirão São

Bartolomeu, Zona da Mata de Minas Gerais, utilizando o simulador SWAT. Tese Doutorado, Viçosa, Universidade Federal de Viçosa.

Meaurio M, Zabaleta A, Uriarte J, Srinivasan R, Antigüedad I (2015) Evaluation of SWAT models performance to simulate streamflow spatial origin. The case of a small forested watershed. Journal of Hydrology 525(1):326-334. DOI: https://doi.org/10.1016/j.jhydrol.2015.03.050

Mehnaza A (2017) Projection of future temperature and precipitation for Jhelum river basin in India using Multiple linear regression. International Journal of Engineering Research and Application 6(4):89-101. DOI://doi.org/10.9790/9622-07060489101

Monteiro JAF, Strauch M, Srinivasan R, Abbaspour K, Gucker B (2015) Accuracy of grid precipitation data for Brazil: application in river discharge modelling of the Tocantins catchment. Hydrological Processes 30(1):1419-1430. DOI:

https://doi.org/10.1002/hyp.10708

Moriasi DN, Arnold JG, Van Liew MW, Binger RL, Harmel RD, Veith TL (2007) Model evaluation guidelines for systematic quantification of accuracy in watershed simulations. Transactions of the ASABE 50(1):885-900. 
Muleta MK, Nicklow JW (2005) Sensitivity and uncertainty analysis coupled with automatic calibration for a distributed watershed model. Journal of Hydrology 306(1):127-145. DOI: https://doi.org/10.1016/j.jhydrol.2004.09.005

Nash JE, Suttclife JE (1970) River flow forecasting through conceptual model: Part I: a discussion of principles. Journal of Hydrology 10(3):282-290. DOI: https://doi.org/10.1016/0022-1694(70)90255-6

Neitsch SL, Arnold JG, Kiniry JR, Sprinivasan R, Williams JR (2005) Soil and water assessment tool input/output file documentation version 2005. 530 p. Availabe:

http://www.brc.tamus.edu/swat/downloads/doc/swat20 05/SWAT\%202005\%20io.pdf. Acessed: Apr 11, 2018.

Neto JOM, Silva AA, Mello CR, Júnior AVM (2014) Simulação Hidrológica escalar com o modelo SWAT. Revista Brasileira de Recursos Hídricos 19(1):177-188. DOI: https://doi.org/10.21168/rbrh.v19n1.p177-188

Oliveira LT (2014) Aplicação do modelo SWAT para simular vazões em uma bacia hidrográfica em Aracruz, ES. Dissertação Mestrado, Vitória, Universidade Federal do Espírito Santo.

Perazzoli M, Pinheiro A, Kaufmann V (2013) Efeitos de cenários de uso do solo sobre o regime hídrico e produção de sedimentos na bacia do ribeirão Concórdia - SC. Revista Árvore 37(5):859-869. DOI: http://dx.doi.org/10.1590/S0100-67622013000500008

Pereira DR (2013) Simulação Hidrológica na bacia hidrográfica do rio Pomba usando o modelo SWAT. Tese Doutorado, Viçosa, Universidade Federal de Viçosa.

Pereira DR, Martinez MA, Almeida AQ, Pruski FF, Silva DD, Zonta JH (2014) Hydrological simulation using SWAT model in headwater basin in southeast Brazil. Engenharia Agrícola 34(4):789-799. DOI: http://dx.doi.org/10.1590/S0100-69162014000400018
Pinto DBF (2011) Aplicação do modelo SWAT (Soil and Water Assessment Tool) na simulação hidrossedimentológica em bacia hidrográfica da Serra da Mantiqueira, MG. Tese Doutorado, Universidade Federal de Lavras.

Scolforo JR, Oliveira AD, Carvalho LMT (2008) Zoneamento ecológico-econômico do Estado de Minas Gerais: zoneamento e cenários exploratórios. Lavras, Editora UFLA, 136p.

Tucci CEM (2005) Modelos hidrológicos. Porto Alegre, Editora UFRGS, 678p.

Van Liew MW, Arnold JG, Garbrecht JD (2003) Hydrologic simulation on agricultural watersheds: Choosing between two models. Transactions of the ASAE 46(6):1539-1551. DOI: http://dx.doi.org/ $10.13031 / 2013.15643$

Winchell M, Srinivasan R, Di Luzio M, Arnold J (2009) ArcSWAT 2.3.4 interface for SWAT2005 user's guide. 460 p. Availabe:

http://www.brc.tamus.edu/swat/downloads/doc/swat20 05/SWAT\%202005\%20io.pdf. Accessed: Sep 08, 2018.

Zhang H, Wang B, Liu DL, Zhang M, Feng P, Cheng L, Yu Q, Eamus D (2019) Impacts of future climate change on water resource availability of eastern Australia: A case study of the Manning River basin. Journal of hydrology 573(1):49-59. DOI: https://doi.org/10.1016/j.jhydrol.2019.03.067

Zhu Q, Zhang X, Ma C, Gao C, Xu YP (2016) Investigating the uncertainty and transferability of parameters in SWAT model under climate change, Hydrological Sciences Journal 61(5):914-930. DOI: 10.1080/02626667.2014.1000915 